\title{
Evaluation of E-Banking Dimensions by Greek Customers
}

\author{
Efstathios Dimitriadis ${ }^{1}$, Athanasios Mandilas ${ }^{2}$, Dimitrios Maditinos ${ }^{3}$
}

\begin{abstract}
:
The use of electronic banking is increased rapidly worldwide. However, the percentage of Greek e-banking users, even if it has increased, is still very low. The adoption of e-banking depends on some factors which are connected with the services that the banks offer and the satisfaction from these factors influences, the overall satisfaction. The aim of this study was the exploration of the perception of Greek e-banking users about the factors affecting the satisfaction from the use of e-banking and moreover the influence of their experiences in the perception's formation. In order to achieve the aims of this study a research was realized, using a structured questionnaire, in 354 users of e-banking. The results show that Greek customers are quite satisfied from the e-banking dimensions and moreover the dimensions that mostly affect the overall satisfaction are "trust" and "convenience/ usefulness".
\end{abstract}

\section{Key Words:}

E-Banking, Greek customers' behavior, services' evaluation, familiarity

JEL Classification: 621

\footnotetext{
${ }^{1}$ Corresponding Author: Assistant Professor of Applied Statistics, Kavala Institute of Technology, Department of Business Administration,e-mail: edimit@teikav.edu.gr.

${ }^{2}$ Assistant Professor, Department of Accountancy, Kavala Institute of Technology, e-mail: smand@teikav.edu.gr

${ }^{3}$ Assistant Professor Department of Business Administration, Kavala Institute of Technology, e-mail:dmadi@teikav.edu.gr.
} 


\section{Introduction}

The possibility to fulfil banking transactions with the use of Internet, referred as electronic banking (e-banking), is increased rapidly and while, before few years, it constituted an unusual banking service today it is offered by all the banks. Lau (1997) defines e-banking as the distribution of banking services via a network of open access, directly in the customer. It was characterized as an innovation used by the customers who want to realise, in electronic way, transactions as the opening of account, the transport of money the payment of cards (Corrocher, 2006; Simson, 2002). E-banking is growing quickly from being a rarely banking service to one that can be found at many banks. Despite the fact that brick and mortar branches are the main banking distribution channels, people have started to prefer the e-banking to carry out their transaction by themselves, without the need to visit a bank branch. It is considered to become the favorable, alternative, distribution channel, because, it offers financial services with convenience, security, privacy and quality information about financial products, without place or time limits and in better prices (Guerrero at el., 2007). The development of e-banking is a result of an increasing use of personal computers, the refined Internet connections, the widely use of Internet by people at home and work, and the lower prices in services which are offered from the e-banking (Hernando and Nieto, 2007). A recent research for Europeans reveals that the e-banking usage leads the customers to get the ownership of more financial product and services. Also the aspect of trust, for safe transactions via e-banking, affects significantly user's decision for the adoption of the E-banking services (Guerrero et al., 2007).

E-banking is a service which is growing rapidly in developed countries such as Finland, UK, the US, Italy, Spain, and in countries with emerging economies such as India, Hong Kong, South Korea, Turkey, Malaysia and Estonia. People in Greece have a different attitude towards new technologies, such as e-banking. They have started to trust the new services recently, and they want to be benefited from all the advantages offered by e-banking services (htpp://www.ber.gr; http://blog.isotopon.com). In 2001, e-banking users, in Greece, were not over 150,000 . In 2004 the users were 500,000, in 2006, 800,000, in 2007, 996,500, in the end of 2008 it is estimated to be 1,500,000 (htpp://www.ber.gr).

\section{Literature review}

Many researches in the past have examined the factors affecting the adoption of ebanking. Nowadays, a lot of people realise their banking transactions electronically, therefore evaluating their satisfaction in e-banking services constitutes the next logical step in the scientific researches. 
It is common to measure the success of an Information System with the user's satisfaction (Zviran and Erlich, 2003; Doll et al., 2004; Thalassinos et al., 2013). Satisfaction can be defined as the user's perception which influences his/her intention to evaluate and use a service such as the e-banking services (Casalo et al., 2008). According to Zviran et al. (2006), the satisfaction of the users is a critical construct because it is related to other important variables, including systems analysis and design. Lee and Chung (2009) state that in web-based systems, in particular, satisfaction can depend on various factors, including web design, content, user interface, navigation and information structure. The link between "satisfaction" and "service quality" construct is emphasized in several studies (Jamal and Naser, 2002; Ndubisi, 2006). Based on the work of Parasuraman et al. (1985) other researches, in the banking literature, report that there are two main dimensions affecting customer satisfaction: (1) The quality of services provided by the bank which are "reliability", "security", "functionality", "accuracy" and "speed" (Jamal and Naser, 2002, 2003); (2) the quality of the relationship with the bank. Relationship drivers seem to be even more important and include "responsiveness", "competences", "assurance", "trust", “friendliness", “courtesy", "availability", "commitment", "flexibility", and "communication" (Jamal and Naser, 2002, 2003; Jones, 2004; Manrai and Manrai, 2007; Thalassinos, Maditinos and Paschalidis 2012).

Many factors affecting the satisfaction were presented in the literature and all of them are measured by the use of a lot of items which are, in most cases, different. In this study the factors which were employed, in order to determine the satisfaction from the use of e-banking, were selected from various studies and are then presented.

Security: The concept of security in transactions is one of the most important factors that influence the e-banking adoption. Customers have the perception of being protected against threats. As Kalakota and Whinston (1997) state "security is the customers' perception of the degree of protection against threats, such as, economic hardship to data or network resources in the form of destruction, disclosure, modification of data, denial of service, and/or fraud, waste and abuse". If customers think that they are not protected, they are not willing to use Internet for their activities.

Status: It was used to measure the influence of the e-banking usage on the selfimage of the user (Gerand and Cunningham, 2003). Status refers to impression management and influences the consumer's image in the eyes of other consumers (Holbrook, 1999).

Exploration: Baumgather and Steenkamp (1996) state that the exploratory consumer attitude is an inner motivated consumption process that is separated in two 
dimensions: exploratory acquisition of products (EAP), and explanatory information seeking (EIS). Exploratory information seeking includes consumer activities such as the reading of daily news in bank website, or the opinions which the users are able to exchange on website.

Trust: The customers' trust in a vendor is fundamental and a customer expects from a vendor to protect him from undesirable situations. Mayer et al. (1995) and Rousseau et al. (1998) defined trust as "a psychological state which leads to the willingness of customer to perform banking transactions on the Internet, expecting that the bank will fulfill its obligations, irrespective of customer's ability to monitor or control bank's actions".

Convenience/usefulness: Convenience refers to the benefit of time saving and the advanced services that a consumer enjoys by using e-banking services replacing the banks branches (Polatoglou and Ekin, 2001). The perceived usefulness is considered to be a basic factor that influences the user's adoption of e-banking services. Customers decide to use e-banking when they believe that they will have advantages of the usage such as the improvement of their job performance, low transaction cost etc (Davis et al., 1989). The overall satisfaction from e-banking services, as have shown many researches, is influenced by the consumer's perception in the various dimensions associated with e- banking services. Furthermore, the factors forming the e-banking dimensions are affected by user's experience (often referred as familiarity) in the Internet. Familiarity, in the context of Internet and electronic commerce, has received attention recently (Maenpaa et al., 2008). In the Internet context, familiarity means experience in using the Internet in general (Gefen, 2000; Corbitt et al., 2003; So et al., 2005). Ward and Lee (2000) argue that users with high level of experience search less and are more confident when operating online. As has been found familiarity in using computers and new technology affect positively consumer attitude with regard to usage of electronic banking (Karjaluoto et al., 2002).

This study is trying to determine the degree of agreement of Greek e-banking users with the basic e-banking dimensions and furthermore to evaluate the overall satisfaction from the use of e-banking. It also aims to explore the impact of the basic dimensions on satisfaction and moreover the influence of familiarity in the degree of satisfaction.

\section{Methodology}

\subsection{Sample and data collection}

In order to achieve the aims of this study a research was realized among the Greek ebanking users with the use of a structured questionnaire as research instrument. The questionnaires have been sent via Internet after a random choice by the data base of 
Greek banks customers. 354 out of 1011 questionnaires have been returned and suitably for use (response rate 35\%). The demographic characteristics of the sample are presented in the Table 1.

Table 1: E-banking users' demographic characteristics

\begin{tabular}{|l|l|r|}
\hline \multicolumn{2}{|l|}{} & Percentage \\
\hline Gender & Male & $59,1 \%$ \\
\hline & Female & $40,9 \%$ \\
\hline Age & & $6,8 \%$ \\
\hline & -24 & $77,3 \%$ \\
\hline & $25-40$ & $14,2 \%$ \\
\hline & $41-55$ & $1,7 \%$ \\
\hline & $55+$ & \\
\hline Education & & $1,2 \%$ \\
\hline & Elementary & $9,6 \%$ \\
\hline & Medium & $54,2 \%$ \\
\hline & High & $35,0 \%$ \\
\hline & M.Sc / Ph.D. & $5,7 \%$ \\
\hline Monthly Income & & $40,1 \%$ \\
\hline & $-800 €$ & $26,0 \%$ \\
\hline & $801-1200 €$ & $28,2 \%$ \\
\hline & $1201-1400 €$ & \\
\hline & $+1400 €$ & $30,5 \%$ \\
\hline Occupation & & $60,5 \%$ \\
\hline & Public employee & $5,6 \%$ \\
\hline & Private employee & $0,6 \%$ \\
\hline & Entrepreneur & $2,8 \%$ \\
\hline & Unemployed &
\end{tabular}

\subsection{Measures}

The questionnaire consists of four sections. The first section is referred to the demographic characteristics of the sample's individuals. The demographic characteristics create the respondents profile and are believed that influence in the intention of customers to adopt the Internet services and especially the e-banking services (Maenpaa et al., 2008; Litter and Melanthiou, 2006; Erikson and Nilson, 2007).

The second section of the questionnaire measures the e-banking experience (familiarity) of users. For measuring users experience it was first examined (a) the length of use, (b) the frequency, and (c) time spend connected. About the e-banking length measurement, three categories were identified: (1) less than one year, (2) between one and tree years, and (3) more than three years (Maenpaa et al., 2008). About the e-banking frequency measurement, five options where provided: (1) once 
a month, (2) 2-3 times a month, (3) 1-3 times a week, (4) 4-6 times a week, (5) daily. For the time spend, four options were used: (1) less than an hour per week, (2) between 1 and 4 hours per week, (3) between 4 and 10 hours per week, (4) more than 10 hours per week (Castaneda et al., 2007).

The third section of questionnaire is constituted by 35 items, adopted by various researches, which create the five dimensions of e-banking transactions and which were called to evaluate the users. The five dimensions are: (a) security, (b) social status, (c) exploration, (d) trust, (e) convenience/usefulness.

The fourth section measures the satisfaction from the use of e-banking and is constituted by 3 items, adopted by work of Casalo et al. (2008). Details about the items and their sources can be found in the Appendix A.

All items, in the third and fourth part, were statements and the respondents were asked to indicate on a five- point Likert scale, ranging from $1=$ strongly disagree to $5=$ strongly agree, the degree to which they agreed with the statements.

\subsection{Validation of research instrument}

The appropriateness of the research instrument was tested for content validity, construct validity, and reliability.

Content validity is based on the extent to which a measurement reflects the specific intended domain of content (Carmines and Zeller, 1991). Content validity in our research was established from the existing literature, and our measures were constructed by adopting constructs validated by other researchers. Moreover, a pilot test in a panel of experts (academics and professionals) was conducted.

Construct validity was examined by assessing convergent validity and discriminant validity (Chin, 1998). Before testing for convergent and discriminant validity, in the second, third and fourth part of the questionnaire, an exploratory factor analysis (EFA) was performed. EFA is applied when the structure of the model is not known or specified a priori and the data are used in order to determine the structure (Timm, 2002). For the extraction of the factors the principal component methods was used, with Varimax rotation which is one of the most popular methods of orthogonal rotation (Sharma, 1996). The appropriateness of data for factor analysis were tested with the Bartlett's test of sphericity and the measure of Kaiser-Mayer-Olkin (KMO) which express the degree to which some items belongs to the same factor. Sharma (1996) notes that the KMO must be greater than 0.8 , however values greater than 0.6 are considered as acceptable. For the determination of the number of the factors the criterion of eigenvalue was used. Factors whose eigenvalue is over 1 are selected (Zampeta, 2012). Finally, for the test of significance of the items which create the 
factors, their loadings were checked. In a sample of more than 350 individuals, a loading more than 0.30 is considered as significant (Haier et al., 1995).

The first factor analysis for the 3 items which measure the familiarity of the users in e-banking transactions gave us acceptable results, as shown in Table 2.

Table 2: Users' experience factor analysis

\begin{tabular}{|l|l|c|}
\hline \multicolumn{1}{|c|}{ Factor } & \multicolumn{1}{|c|}{ Items } & Loadings \\
\hline \multirow{4}{*}{ Familiarity } & $\begin{array}{l}\text { For how long have you been using the } \\
\text { E- banking Services? }\end{array}$ & 0,716 \\
\cline { 2 - 3 } & $\begin{array}{l}\text { How often do you use the Internet for } \\
\text { banking services? }\end{array}$ & 0,913 \\
\cline { 2 - 3 } & $\begin{array}{l}\text { How much time do you spend } \\
\text { connected to the Internet for banking } \\
\text { services? }\end{array}$ & 0,875 \\
\hline $\begin{array}{l}\text { Cronbach's alpha index: } 0,775 \\
\text { KMO }=0,638 \\
\text { Bartlett's test of sphericity: Approx. Chi Square }=315,19 ; \mathrm{df}=3 \quad \text { Sig. }=0,000 ; \\
\text { total variance explained }=70,363 \% \text {; eigenvalue }=2,111\end{array}$ \\
\hline
\end{tabular}

The second factor analysis for the 35 items, which constitutes the dimensions of ebanking, gave us 6 factors initially. In order to achieve more reliable solution were eliminated the items which loading equally to more than one factor and items with load less than 0,35. After the elimination of 11 items the factor analysis was rerun and gave us five factors which explained the $64.44 \%$ of the total variance, KMO index with a value of 0.894 and a significant Bartlett's test. The results of factor analysis, in details, are presented in Table 3.

Table 3: Factor analysis for e-banking dimensions

\begin{tabular}{|l|r|r|r|r|}
\hline Factors & $\begin{array}{c}\text { Number } \\
\text { of items }\end{array}$ & Eigenvalue & $\begin{array}{c}\text { Percent of } \\
\text { variance }\end{array}$ & $\begin{array}{c}\text { Cronbach's } \\
\text { alpha }\end{array}$ \\
\hline $\begin{array}{l}\text { Convenience / } \\
\text { Usefulness }\end{array}$ & 9 & 8,379 & $18,088 \%$ & 0,868 \\
\hline Security & 4 & 1,546 & $10,916 \%$ & 0,808 \\
\hline Status & 4 & 2,351 & $12,815 \%$ & 0,878 \\
\hline Exploration & 3 & 1,185 & $8,988 \%$ & 0,772 \\
\hline Trust & 4 & 1,736 & $12,514 \%$ & 0,791 \\
\hline Total & 24 & & & \\
\hline $\begin{array}{l}\text { KMO =0,875 } \\
\text { Bartlett's test of sphericity: Approx. Chi Square }=4.134 ; 88 \mathrm{df}=27 ; \text { Sig. }=0,000 ; \\
\text { total variance explained =63,321\% }\end{array}$ \\
\hline
\end{tabular}

Finally, factor analysis for the 3 items of satisfaction gave us one factor which explains the $84.266 \%$ of total variance. The KMO statistic is sufficient as its value is 0.730 and is also statistically significant. 
International Journal of Economics \& Business Administration, I (1), 2013

Efstathios Dimitriadis - Athanasios Mandilas - Dimitrios Maditinos

Table 4: Factor analysis for satisfaction

\begin{tabular}{|l|l|c|}
\hline \multicolumn{1}{|c|}{ Factor } & \multicolumn{1}{|c|}{ Items } & Loadings \\
\hline \multirow{4}{*}{ Satisfaction } & $\begin{array}{l}\text { I think that I made the correct decision to } \\
\text { use Internet Banking website and I am } \\
\text { satisfied }\end{array}$ & 0,900 \\
\cline { 2 - 3 } & $\begin{array}{l}\text { In general terms, I am satisfied with the } \\
\text { way that the Internet Banking website that I } \\
\text { use, is carrying out transactions }\end{array}$ & 0,944 \\
\cline { 2 - 3 } & $\begin{array}{l}\text { In general, I am satisfied with the service I } \\
\text { have received from the Internet Banking } \\
\text { website }\end{array}$ & 0,910 \\
\hline $\begin{array}{l}\text { Cronbach's Alpha index= 0,906; } \\
\text { KMO =0,730 } \\
\text { Bartlett's test of sphericity: Approx. Chi Square }=684,231 ; \mathrm{df}=3 ; \text { Sig. }=0,000 ; \\
\text { total variance explained = 84,266\%; eigenvalue }=2,528\end{array}$ \\
\hline
\end{tabular}

Convergent validity relates to the degree to which multiple methods of measuring a variable provide the same results (Spector, 1992; Churchill, 1979) and is considered acceptable when all item loadings are greater than 0.5 (Wixom and Watson, 2001) and the items for all construct load onto only one factor with an eigenvalue greater than 1 (Kim et al., 2008). In our case the loadings of all items are greater than 0.5 (Appendix B), the minimum eigenvalue of the created factors is 1.175 (Tables 2, 3, and 4), and therefore there is evidence of convergent validity.

Discriminant validity deals with the concept that dissimilar constructs should be different (Burns and Bush, 1995). In order to demonstrate that the constructs are distinct a matrix containing the correlation coefficients among the constructs and, in the diagonal of the matrix the Cronbach's alpha coefficients was created (Table 5). The correlation coefficients within a column should be less than the coefficient alpha found in the diagonal (Churchill, 1979). The results in the table5 support the claim of discriminant validity and demonstrate that the constructs are distinct dimensions.

Table 5: Correlation matrix of e-banking dimensions

\begin{tabular}{lccccc}
\hline & $\mathbf{1 .}$ & $\mathbf{2 .}$ & $\mathbf{3 .}$ & $\mathbf{4 .}$ & $\mathbf{5 .}$ \\
\hline 1. Security & $0,808^{\mathrm{a}}$ & & & & \\
2. Status & $0,323^{* *}$ & $0,878^{\mathrm{a}}$ & & & \\
3. Exploration & $0,297^{* *}$ & $0,352^{* *}$ & $0,772^{\mathrm{a}}$ & & \\
4. Trust & $0,550^{* *}$ & $0,398^{* *}$ & $0,379^{* *}$ & $0,791^{\mathrm{a}}$ & \\
5. Convenience/ usefulness & $0,608^{* *}$ & $0,388^{* *}$ & $0,362^{* *}$ & $0,498^{* *}$ & $0,868^{\mathrm{a}}$ \\
\hline${ }^{\mathrm{a}}$ Cronbach's alpha index & & & & & \\
** Correlation is significant at the 0.01 level (2-tailed). & & &
\end{tabular}


For testing reliability, which is one of the most important criteria for the evaluation of the questionnaire (Chu and Murrmann, 2006), Cronbach alpha index was used. Nunally (1978) suggests that Cronbach's alpha should be greater than 0.7 in order to be characterized as reliable a construct.

The reliability index for the first factor of "familiarity" is 0,775 (Table 2) and the reliability indices for all the factors of e- banking dimensions ranking from 0.772 to 0.878 (Table 3). Finally, the reliability index for the "satisfaction is 0.906 (Table 4). Thus, all the factors are characterized reliable, as their values are greater than the suggested point of 0.7 .

\section{Data analysis - Results}

After the validation of the instrument the responses to these research questions were averaged to form the final score for the factors. The first step in the data analysis was the calculation of basic statistics for familiarity, e-banking dimensions, and satisfaction.

The mean score for familiarity is 1.66 and shows that the level of familiarity is not enough high. Then, the familiarity score was separated into quartiles and the first quartile represents the "low familiar users" ( $\mathrm{N}=141,41.8 \%)$ who have low experience on e-banking services. The second and third quartiles, both of them, conclude the category of "moderately familiar users" $(\mathrm{N}=126,37.4 \%)$. The fourth quartile represents "highly familiar users" $(\mathrm{N}=70,20.8 \%)$ who use the e-banking services very often, for a long time, and are connected with bank's website for long time.

Observing the values on the Table 5 it is obvious that the respondents feel more than secure than insecure as the mean score is 3.54 . The respondents believe that the use of e-banking is not a factor that improves their status (3.13). They also trusting the e-banking transactions (3.68) and believe that are convenient and useful (4.04). Finally, they are satisfied from the use of e-banking (4.05).

The coefficient of variation for all the dimensions of e-banking is greater than $15 \%$. This is an indication of a significant differentiation in the level of agreement among the respondents. Maenpaa et al. (2008) indicated that familiarity affects consumer perceptions on the various e-banking dimensions.

Table 5: Basic statistics

\begin{tabular}{|l|c|r|r|r|c|}
\hline & Min. - Max. value & Mean & Median & Std. Deviation & C.V \\
\hline Familiarity & $1-4$ & 1.66 & 1.67 & 0.550 & $33.13 \%$ \\
Security & $1-5$ & 3.54 & 3.50 & 0.849 & $23.98 \%$ \\
Status & $1-5$ & 3.13 & 3.25 & 0.960 & $30.68 \%$ \\
Exploration & $1-5$ & 3.31 & 3.33 & 0.936 & $28.24 \%$ \\
\hline
\end{tabular}


International Journal of Economics \& Business Administration, I (1), 2013 Efstathios Dimitriadis - Athanasios Mandilas - Dimitrios Maditinos

\begin{tabular}{|l|l|l|l|l|l|}
\hline Trust & $1-5$ & 3.68 & 3.75 & 0.796 & $21.60 \%$ \\
Convenience/Usefulness & $1-5$ & 4.04 & 4.11 & 0.662 & $16.38 \%$ \\
Satisfaction & $1-5$ & 4.05 & 4.11 & 0.663 & $16.37 \%$ \\
\hline
\end{tabular}

For determining differences in means of the perceptions on the five dimensions of ebanking which are owed in the different level of user's familiarity a one-way ANOVA was used. From the results presented in Table 6 arises that only security and trust do not depend on the level of familiarity. Especially, the high familiar respondents feel that their image is improved in the eyes of other consumers because the use of e-banking. Furthermore, they are more satisfied than the others from the e-banking services and transactions and also believe that e-banking is convenient and useful.

Table 6: ANOVA by level of familiarity

\begin{tabular}{|l|c|c|}
\hline & F- Value & Sig. \\
\hline Security & 2.586 & 0.077 \\
\hline Status & 3.019 & $0.049^{*}$ \\
\hline Exploration & 3.238 & $0.040^{*}$ \\
\hline Trust & 1.675 & 0.189 \\
\hline Usefulness/ Convenience & 3.864 & $0.022^{*}$ \\
\hline Satisfaction & 4.130 & $0.017^{*}$ \\
\hline
\end{tabular}

*Significant at 0.05 level or lower

In order to explore differences in the level of familiarity which are owned in the demographic characteristics of respondents a $\chi^{2}$-test of independence was performed. The results show that the level of familiarity depends on gender $\left(\chi^{2}\right.$ $=7,978$ with $p$-value $=0,019)$, educational level $\left(\chi^{2}=10,90\right.$ with $p$-value $\left.=0,091\right)$ and monthly income $\left(\chi^{2}=15,10\right.$ with $p$-value $\left.=0,019\right)$.

Table 7: $\chi^{2}$-test of independence

\begin{tabular}{|l|l|c|c|c|c|c|}
\hline \multicolumn{2}{|l|}{} & \multicolumn{3}{|c|}{ Level of familiarity } & \multicolumn{2}{c|}{$\chi^{2}$ - test } \\
\hline \multicolumn{2}{|c|}{ Personal characteristics } & Low & Moderate & High & $\chi^{2}$ & p-value \\
\hline Gender & Male & 35.8 & 38.5 & 25.7 & 7.978 & $0.019^{*}$ \\
\hline \multirow{2}{*}{ Age } & Female & 48.7 & 36.1 & 15.2 & & \\
\hline & -24 & 33.8 & 41.7 & 25.0 & 4.821 & 0.567 \\
\hline & $25-40$ & 41.0 & 39.5 & 19.5 & & \\
\hline & $41-55$ & 53.1 & 26.5 & 20.4 & & \\
\hline Education & over 55 & 33.3 & 33.3 & 33.3 & & \\
\hline & Elementary & 50.0 & 0.0 & 50.0 & 10.90 & $0.091^{* *}$ \\
\hline
\end{tabular}




\begin{tabular}{|l|l|c|c|c|c|c|}
\hline & High & 45.0 & 33.9 & 21.1 & & \\
\hline & M.Sc/Ph.D & 35.0 & 41.7 & 23.3 & & \\
\hline Income & $-800 €$ & 30.0 & 60.0 & 10.0 & 15.10 & $0.019^{*}$ \\
\hline & $801-1200 €$ & 51.1 & 32.8 & 16.0 & & \\
\hline & $1201-1400 €$ & 39.3 & 40.4 & 20.3 & & \\
\hline & $+1400 €$ & 34.0 & 36.1 & 29.9 & & \\
\hline Occupation & $\begin{array}{l}\text { Public } \\
\text { employee }\end{array}$ & 44.7 & 35.0 & 20.3 & 7.82 & 0.451 \\
& $\begin{array}{l}\text { Private } \\
\text { employee }\end{array}$ & 43.1 & 36.6 & 20.3 & & \\
\hline & Student & 40.0 & 40.0 & 20.0 & & \\
\hline & Entrepreneur & 20.0 & 30.0 & 50.0 & & \\
\hline & Unemployed & 0.0 & 100.0 & 0.0 & & \\
\hline
\end{tabular}

*Significant at 0.05 level or lower

** Significant at 0.1 level or lower

The degree of agreement on e-banking dimensions, as it is expected, reflects on the degree of overall customer's satisfaction. In order to estimate the dimensions that affect significantly and more than others in the satisfaction, a regression model was created. The familiarity is a factor that can differentiate the effect of various dimensions on overall customer's satisfaction. Three regression models, one for each level of familiarity, were employed. The dependent variable was the "satisfaction" and the independent variables were the five dimensions of e-banking, for all models. The results of the regression analyses for all models are presented in Table 8 .

In the first regression model that refers to the overall sample the independent variables explain the $89.8 \%$ of the total variance $\left(\mathrm{R}^{2}=0.898\right)$. However, only three variables (status, trust, and usefulness/convenience) are significant predictors of customer's satisfaction. Specifically, "usefulness/convenience", with a coefficient of 0,837 ( sig. $<0.001$ ), is the dimension that affects more to the satisfaction followed by trust $(0.151$ and sig. $<0.001)$.

The second regression model refers only to the low familiar users and the $\mathrm{R}^{2}$ indicates that the amount of variance explained by the model is $89 \%$. The three variables which are significant predictors of customer's satisfaction are "exploration", "trust" and "usefulness/ convenience". The dimensions that affect more to the satisfaction are, as in the first model, usefulness/convenience with a coefficient of 0.812 (sig. $<0.001)$ and trust (0.141 and sig. $<0.001)$. 
The third regression model is created by the moderate familiar users and the independent variables explain the $94.5 \%$ of the total variance. The three variables which are statistically significant and affect to the user's satisfaction are, with order of classification, "usefulness/convenience" (0.870 and sign. $<0.001)$, "trust" $(0.141$ and sig. $<0.001)$ and "status" (0.082 and sig. $<0.01)$.

The last regression model is created by high familiar users and the independent variables explain the $78.7 \%$ of the total variance. Only two independent variables are statistically significant and affect to the user's satisfaction. The two variables are, as in all models, the "usefulness/convenience" with a coefficient of 0.870 (sign. $<0.001)$ and "trust" $(0.190$ and sign. $<0.01)$.

Table 8: Four regression models ${ }^{\mathrm{a}}$

\begin{tabular}{|c|c|c|c|c|c|c|c|c|}
\hline & \multicolumn{2}{|c|}{$\begin{array}{c}\text { Total } \\
\text { Sample } \\
\end{array}$} & \multicolumn{2}{|c|}{$\begin{array}{c}\text { Low } \\
\text { Familiarity }\end{array}$} & \multicolumn{2}{|c|}{$\begin{array}{c}\text { Moderate } \\
\text { Familiarity }\end{array}$} & \multicolumn{2}{|c|}{$\begin{array}{c}\text { High } \\
\text { Familiarity } \\
\end{array}$} \\
\hline Dimensions & Beta & Sig. & Beta & Sig. & Beta & Sig. & Beta & Sig. \\
\hline Security & -0.006 & 0.804 & 0.022 & 0.576 & -0.026 & 0.388 & -0.033 & 0.638 \\
\hline Status & 0.046 & 0.023 & 0.031 & 0.349 & 0.082 & 0.001 & -0.007 & 0.917 \\
\hline Exploration & 0.024 & 0.226 & 0.071 & 0.031 & -0.019 & 0.469 & 0.020 & 0.755 \\
\hline Trust & 0.151 & 0.000 & 0.141 & 0.000 & 0.141 & 0.000 & 0.190 & 0.008 \\
\hline $\begin{array}{l}\text { Usefulness/ } \\
\text { Convenience }\end{array}$ & 0.837 & 0.000 & 0.812 & 0.000 & 0.870 & 0.000 & 0.838 & 0.000 \\
\hline $\mathrm{R}^{2}$ & \multicolumn{2}{|c|}{$\frac{1}{0.898}$} & \multicolumn{2}{|c|}{$\frac{1}{0.890}$} & \multicolumn{2}{|c|}{$\frac{1}{0.945}$} & \multicolumn{2}{|c|}{$\frac{1}{0.787}$} \\
\hline $\mathrm{F}$ & \multicolumn{2}{|c|}{583,195} & \multicolumn{2}{|c|}{217,670} & \multicolumn{2}{|c|}{415,330} & \multicolumn{2}{|c|}{47,304} \\
\hline Sig. & \multicolumn{2}{|c|}{0.000} & \multicolumn{2}{|c|}{0.000} & \multicolumn{2}{|c|}{0.000} & \multicolumn{2}{|c|}{0.000} \\
\hline
\end{tabular}

${ }^{\mathrm{a}}$ Dependent variable: satisfaction

\section{Conclusions}

The use of e-banking services by Greek customers every year is increased with rapid steps. The exploration of the perception of Greek e-banking users about the factors affecting the satisfaction from the use of e-banking was the main objective of this study. The dimensions which are significant predictors and affect the satisfaction more than the others, independently from the level of familiarity, are the "trust" and the "convenience/usefulness". Trust is considered as a basic customer perception and marks the user's confidence that the bank protects him from false transactions. The perception that using e-banking the works are realized better and easier drives to the satisfaction from the e-banking services. In the case of low familiar users the "exploration" is also a significant predictor and for moderate familiar users the "status" constitutes another significant predictor of satisfaction.

The results indicate also that the most of Greek customers are characterized as "low familiar" with e-banking services. Moreover, they are satisfied enough from e- 
banking dimensions and especially from "trust" and "convenience/usefulness". "Trust" and "security" do not depend from the level of familiarity, something that is happening for "convenience/usefulness", "status" and "exploration". The level of familiarity of Greek customers depends on gender, education and income.

Based on our findings it is in the best interest of e-banking service providers to gain the trust and usefulness of their customers. They must make more effort to improve the sense of security to the customers in order to attract more and more people that until now do not use e-banking or use it in limited extend.

\section{References}

Baumgartner, R.H. and Steenkamp, J. (1996), "Exploratory Consumer Buying Behavior: Conceptualization and Measurement", International Journal of Research in Marketing, 13(2), pp. 121-37.

Burns, A.C. and Bush, R.F. (1995), Marketing Research, Prentice-Hall, Englewood Cliffs, NJ.

Carmines, E.G. and Zeller, R.A. (1991), Reliability and Validity Assessment, Sage, Thousand Oaks, CA.

Casalo, L., Flavian, C.M. and Guinaliu, E. (2008), "The Role of Perceived Usability, Reputation, Satisfaction and Consumer Familiarity on the Website Loyalty Formation Process", Computers in Human Behavior, 24, pp. 325-45.

Castaneda, J.A., Munoz-Leiva, F. and Luque, T. (2007), "Web Acceptance Model (WAM): Moderating Effects of User Experience", Information and Management, 44, pp. 384-96.

Cheng, E., C. Lam, D.Y. and Yeung, C.L. (2006), "Adoption of E-banking: An Empirical Study in Hong Kong”, Decision Support Systems, 42, pp. 1558-1572.

Chin, W.W. (1988), "The Partial Least Squares Approach to Structural Equation Modeling", in Marculides, G.A. (Ed.), Modern Methods for Business Research, Lawrence Erlbaum, Mahwah, NJ.

Chin, W.W., Gopal, A. and Salisbury, W.D. (1997), "Advancing the Theory of Adoptive Structure: The Development of a Scale to Measure Faithfulness of Appropriation", Information Systems Research, (8)4, pp. 342-67.

Chu, K.H. and Murrmann, S.K. (2006), "Development and Validation of the Hospitality Emotional Labor Scale”, Tourism Management, 27, pp. 1181-91.

Churchill, G.A. (1979), "A Paradigm for Developing Better Measures of Marketing Constructs", Journal of Marketing Research, 16, pp. 64- 73.

Corbitt, B.J., Thanasankit, T.H. and Yi, T.H. (2003), "Trust and E-commerce: A Study of Consumer Perceptions", Electronic Commerce Research and Applications, 2(3), pp. 203-15.

Corrocher, N. (2006), "Internet Adoption in Italian Banks: An Empirical Investigation, Research Policy”, 35, pp. 533-544.

Davis, F.D., Bagozzi, R.P. and Warshaw, P.R. (1989), "User Acceptance of Computer Technology: A Comparison of Two Theoretical Models", Management Science, 35(8) pp. 982-1003. 


\section{International Journal of Economics \& Business Administration, I (1), 2013}

Doll, W.J., Deng, X., Raghunathan, T.S., Torkzadeh, G. and Xia, W. (2004), “The Meaning and Measurement of User Satisfaction: A Multigroup Invariance Analysis of the End User Computing Satisfaction Instrument", Journal of Management Information Systems, 2(1), pp. 227-62.

Erikson, K. and Nilson, D. (2007), "Determinants of the Continued Use of Self-service Technology: The Case of E- banking", Technovation, 27, pp. 159-67.

Gefen, D. (2000), "E-commerce: the Role of Familiarity and Trust", The International Journal of Management Science, 28, pp. 725-37.

Gerrard, P. and Cunningham, J.B. (2003), "The Diffusion of E- banking amongst Singapore Consumers", International Journal of Bank Marketing, 21(1), pp. 16-28.

Guerrero, M.M., Ortega Egea, J.M. and González, M.V.R. (2007), “Application of the Latent Class Regression Methodology to the Analysis of Internet Use for Banking Transactions in the European Union", Journal of Business Research, 60, pp. 137-45.

Hair, F.,R. Anderson, Tatham, R. and Black, W. (1995), Multivariate Data Analysis with Readings, Prentice-Hall International, London.

Hernado, I. and Nieto, M.J. (2007), “Is the Internet Delivery Channel Changing Bank's Performance? The Case of Spanish Banks", Journal of Banking and Finance, 31, pp. 1083-99.

Holbrook, M.B. (1999), Consumer Value: A Framework for Analysis and Research, Rutledge Kegan Paul, London.

Jamal, A. and Naser, K. (2003), "Factors Influencing Customer Satisfaction in the Retail Banking Sector in Pakistan", International Journal of Commerce and Management, 13(2), pp. 29-53.

Jones, C. (2004), “Developing a Scorecard for Service Quality”, Management Services, 48, pp. 8-13.

Kalakota, R. and Whinston, A. (1997, Electronic Commerce: A Manager's Guide, Adisson Wesley, Reading, MA.

Karjaluoto, H., Mattila, M. and Pento, T. (2002), "Factors Underlying Attitude Formation Towards Online Banking in Finland", International Journal of Banking Marketing, 20(6), pp. 261-72.

Kim, D.J., Ferrin, D.L. and Rao, H.R. (2008), “A Trust-based Consumer Decision Making Model in Electronic Commerce: The Role of Trust, Perceived Risk, and Their Antecedents", Decision Support Systems, 44, pp. 544-564.

Kolodinsky, J.M., Hogarth, J.M. and Hilgert, M.A., (2004), "The Adoption of Electronic Banking Technologies by US Consumers", The International Journal of Bank Marketing, 22(4), pp. 238-59.

Lau, E. (1997), Government Policy on Smart Card Applications and Internet Banking, Monetary Authority, Hong Kong.

Lee, K.C. and Chung, N. (2009), "Understanding Factors Affecting Trust in and Satisfaction with Mobile Banking in Korea: A Modified DeLone and McLean's Model Perspective, Interacting with Computers", article in press.

Littler, D. and Melanthiou, D. (2006), "Consumer Perceptions of Risk and Uncertainty and the Implications for Behaviour Towards Innovative Retail Services: The Case of Ebanking”, Journal of Retailing and Consumers Services, 13, pp. 431-43.

Maenpaa, K.S., Kale, H., Kuusela, H. and Mesiranta, N. (2008), "Consumer Perceptions of E- banking in Finland: The Moderating Role of Familiarity", Journal of Retailing and Consumer Services, 15, pp. 266-276. 
Manrai, L.A. and Manrai, A.K. (2007), “A Field Study of Customers' Switching Behavior for Bank Services", Journal of Retailing and Consumer Service, 14(7), pp. 208-15.

Mayer, R.C., Davis, J.H. and Schoorman, F.D. (1995), "An Integrative Model of Organizational Trust”, Academy of Management Saddle River, 20(3), pp. 709-34.

Ndubisi, N.O. (2006), "A Structural Equation Modelling of the Antecedents of Relationship Quality in the Malaysia Banking Sector", Journal of Financial Services Marketing, 11(2), pp. 131-141.

Nunally, J.C. (1978), Psychometric Theory, McGraw- Hill, New Delhi.

Pikkarainen, K., Pikkarainen, T., Karjaluoto, H. and Pahnila, S. (2006), "The Measurement of End-User Computing Satisfaction of the Online Banking Services: Empirical Evidence from Finland", International Journal of Bank Marketing, 24(3), pp. 158-73,

Polatoglu, V.N. and Ekin, S. (2001), “An Empirical Investigation of the Turkish Consumers' Acceptance of E-banking Services”, International Journal of Bank Marketing, 19(4), pp. $156-165$.

Sharma, S. (1996), Applied Multivariate Techniques, Willey, NY.

Shing, C.Y., Grant, K. and David, E. (2007), "Factors Affecting the Adoption of E- banking in Hong Kong-implications for the Banking Sector", International Journal of Information Management, 27, pp. 336-51.

Simpson, J. (2002), "The Impact of the Internet in Banking: Observations and Evidence from Developed and Emerging Markets", Telematics and Informatics, 19, pp. 315-30.

So, M.W.C., Wong, D.T.N. and Scull, D. (2005), "Factors Affecting Intentions to Purchase via the Internet”, Industrial Management \& Data Systems, 105(9), pp. 1225-44.

Sohail, M.C. and Shanmugham, B. (2003), "E-banking and Customer's Preferences in Malaysia: An empirical investigation”, Information Sciences, 150, pp. 207-17.

Spector, P.E. (1992), "Summated Rating Scale Construction: An Introduction", Sage University Paper Series on Quantitative Applications in the Social Sciences, Newbury Park, CA.

Suh, B. and Han, I. (2002), "Effect of Trust on Consumer Acceptance of E-banking", Electronic Commerce Research and Applications, 1, pp. 247-63.

Sundarraj, R.P. and Wu, J. (2005), "Using Information-systems Constructs to Study Onlineand Telephone-banking Technologies", Electronic Commerce Research and Applications, 4, pp. 427-43.

Thalassinos, I.E., Keisidou, E.L., Sarigiannidis and Maditinos, D. (2013), "Customer Satisfaction, Loyalty and Financial Performance: A Holistic Approach of the Greek Banking Sector", International Journal of Bank Marketing, Vol. 31, issue 4, pp. 1-47.

Thalassinos, I.E., Maditinos, D. and Paschalidis, A. (2012), "Observing Evidence of Insider Trading in the Athens Stock Exchange (ASE)", Journal of Economic Structures, 1:8, available at www.journalofeconomicstructures.com/content/1/1/8 [accessed Dec. 3].

Timm, N. (2002), Applied Multivariate Analysis, Springer- Verlag, New York.

Wixom, B.H. and Watson, H.J. (2001), "An Empirical Investigation of the Factors Affecting Data Warehousing”, MIS Quarterly 25(1), pp. 17-41.

Zampeta, V. (2012), "How Corporate Governance and Globalization Affect the Administrative Structure of the Greek Shipping Industry", Journal of Global Business and Technology, Vol. 8, No 2, pp. 48-58.

Zikmund, W.G. (1997), Business Research Methods for Worth, Dryden Press, TX.

Zviran, M. and Erlich, Z. (2003), "Measuring IS User Satisfaction: Review and Implications", Communications of the AIS, 12(5), pp. 81-104. 
Zviran, M., Glezer, C. and Avni, I. (2006), "User Satisfaction from Commercial Web Site: The Effect of Design and Use", Information \& Management, 43(2), pp. 157-78.

\section{Appendix A}

\begin{tabular}{|c|c|c|}
\hline No & Statements by Factor & Authors \\
\hline & Security & \\
\hline 1 & $\begin{array}{l}\text { By using EB I keep my privacy so that other } \\
\text { people won't know about my bank transactions }\end{array}$ & $\begin{array}{l}\text { Maenpaa et al., } \\
\text { (2008) }\end{array}$ \\
\hline 2 & $\begin{array}{l}\text { I am not afraid that in EB mistakes occur more } \\
\text { easily than at bank office }\end{array}$ & $\begin{array}{l}\text { Maenpaa et al., } \\
\text { (2008) }\end{array}$ \\
\hline 3 & $\begin{array}{l}\text { When I use EB my money is as safe as when I use } \\
\text { other banking services }\end{array}$ & $\begin{array}{c}\text { Kolodinsky et al., } \\
\text { (2004) }\end{array}$ \\
\hline 4 & $\begin{array}{l}\text { The EB is a safe place to transmit sensitive } \\
\text { information and my bank information won't fall } \\
\text { into the wrong hands }\end{array}$ & $\begin{array}{l}\text { Maenpaa et al., } \\
\text { (2008) }\end{array}$ \\
\hline 5 & $\begin{array}{l}\text { I would feel secure sending sensitive information } \\
\text { across the E }\end{array}$ & $\begin{array}{l}\text { Cheng et al., } \\
\text { (2006) }\end{array}$ \\
\hline \multirow[t]{2}{*}{6} & $\begin{array}{l}\text { The EB is a secure means through which to send } \\
\text { sensitive information }\end{array}$ & $\begin{array}{l}\text {.Cheng et al., } \\
\quad(2006)\end{array}$ \\
\hline & Status & \\
\hline 7 & $\begin{array}{l}\text { By using EB I give a modern impression of myself } \\
\text { to other people }\end{array}$ & $\begin{array}{l}\text { Maenpaa et al., } \\
\text { (2008) }\end{array}$ \\
\hline 8 & $\begin{array}{l}\text { By using EB I stand out of ordinary people who } \\
\text { use traditional bank services }\end{array}$ & $\begin{array}{l}\text { Maenpaa et al., } \\
\text { (2008) }\end{array}$ \\
\hline 9 & Using EB gives me a more professional status & $\begin{array}{l}\text { Shing et al., } \\
\text { (2007) }\end{array}$ \\
\hline \multirow[t]{2}{*}{10} & $\begin{array}{l}\text { I can have more prestige than other bank customers } \\
\text { if I use EB services }\end{array}$ & $\begin{array}{l}\text { Shing et al., } \\
\text { (2007) }\end{array}$ \\
\hline & Exploration & \\
\hline 11 & $\begin{array}{l}\text { It would be useful to exchange opinions with other } \\
\text { people in discussion groups about topics related to } \\
\text { banking issues in EB }\end{array}$ & $\begin{array}{l}\text { Maenpaa et al., } \\
\quad(2008)\end{array}$ \\
\hline 12 & $\begin{array}{l}\text { Sometimes it is fun just to browse around and see } \\
\text { what can be found on bank's website }\end{array}$ & $\begin{array}{l}\text { Maenpaa et al., } \\
\text { (2008) }\end{array}$ \\
\hline \multirow[t]{2}{*}{13} & $\begin{array}{l}\text { I would like to read versatile daily news on bank's } \\
\text { website }\end{array}$ & $\begin{array}{l}\text { Maenpaa et al., } \\
(2008)\end{array}$ \\
\hline & Trust & \\
\hline 14 & $\begin{array}{l}\text { Even if I am not monitored I trust EB site to do the } \\
\text { job correctly }\end{array}$ & $\begin{array}{c}\text { Geffen (2000), } \\
\text { Suh and Han (2002) }\end{array}$ \\
\hline 15 & $\begin{array}{l}\text { I trust banks reliability in correcting erroneous } \\
\text { transactions of EB Services usage }\end{array}$ & $\begin{array}{c}\text { Sohail and } \\
\text { Shanmugham (2003) }\end{array}$ \\
\hline 16 & $\begin{array}{l}\text { I have trust in the bank to compensate for losses } \\
\text { due to security using EB Services }\end{array}$ & $\begin{array}{c}\text { Sohail and } \\
\text { Shanmugham (2003) }\end{array}$ \\
\hline
\end{tabular}

\begin{tabular}{|c|l|c|}
\hline 17 & I believe that EB is trustworthy & $\begin{array}{c}\text { Geffen (2000), } \\
\text { Suh and Han (2002) }\end{array}$ \\
\hline 18 & I trust in the benefits of the decisions of the EB site & Suh and Han (2002) \\
\hline 19 & I trust the bank to response to my queries quickly & $\begin{array}{c}\text { Sohail and } \\
\text { Shanmugham (2003) }\end{array}$ \\
\hline
\end{tabular}




\begin{tabular}{|c|c|c|}
\hline 20 & $\begin{array}{l}\text { I get all the information I need for taking care of } \\
\text { my banking transactions more conveniently and in } \\
\text { time, from Internet Bank than from bank office }\end{array}$ & $\begin{array}{l}\text { Maenpaa et al., } \\
(2008)\end{array}$ \\
\hline & Convenience/Usefulness & \\
\hline 21 & $\begin{array}{l}\text { By using EB I get better service than from bank } \\
\text { office }\end{array}$ & $\begin{array}{l}\text { Maenpaa et al., } \\
(2008)\end{array}$ \\
\hline 22 & $\begin{array}{l}\text { By using EB I have more time for my family- } \\
\text { friends-Hobbies }\end{array}$ & $\begin{array}{l}\text { Maenpaa et al., } \\
(2008)\end{array}$ \\
\hline 23 & $\begin{array}{l}\text { I can perform my banking transactions anywhere in } \\
\text { the world }\end{array}$ & $\begin{array}{l}\text { Shing et al., } \\
\text { (2007) }\end{array}$ \\
\hline 24 & $\begin{array}{l}\text { When I want more information or advice from } \\
\text { bank personnel I prefer e-mail or message services } \\
\text { in EB to visiting or calling bank office }\end{array}$ & $\begin{array}{l}\text { Maenpaa et al., } \\
(2008)\end{array}$ \\
\hline 25 & I can enjoy 24 hours banking services & $\begin{array}{l}\text { Shing et al., } \\
\text { (2007) }\end{array}$ \\
\hline 26 & $\begin{array}{l}\text { The EB site that I use keeps its promises and } \\
\text { commitments }\end{array}$ & Suh and Han (2002) \\
\hline 27 & $\begin{array}{l}\text { Using EB site makes it easier to do my banking } \\
\text { activities because the system provide the precise } \\
\text { information I need }\end{array}$ & $\begin{array}{l}\text { Suh and Han (2002) } \\
\text { Pikkarainen et al, } \\
\text { (2006) }\end{array}$ \\
\hline 28 & I find the use of the EB to be advantageous & $\begin{array}{l}\text { Cheng et al., } \\
\text { (2006) }\end{array}$ \\
\hline 29 & $\begin{array}{l}\text { Using EB site the productivity of my banking } \\
\text { activities is enhanced }\end{array}$ & Suh and Han (2002) \\
\hline 30 & EB have better prices than office services & $\begin{array}{l}\text { Erikson and Nilson } \\
(2007)\end{array}$ \\
\hline 31 & $\begin{array}{l}\text { EB use helps me to make managing my accounts } \\
\text { and doing transactions easier }\end{array}$ & $\begin{array}{l}\text { Sundarraj and } \mathrm{Wu} \\
(2005)\end{array}$ \\
\hline 32 & EB use improves my life & $\begin{array}{l}\text { Sundarraj and } \mathrm{Wu} \\
(2005)\end{array}$ \\
\hline 33 & $\begin{array}{l}\text { Using the EB site has a critical role in supporting } \\
\text { my banking activities }\end{array}$ & Suh and Han (2002) \\
\hline 34 & $\begin{array}{l}\text { Using the EB site improves my performance of } \\
\text { banking activities }\end{array}$ & Suh and Han (2002) \\
\hline 35 & I find this EB site useful for my banking activities & Suh and Han (2002) \\
\hline & Satisfaction & \\
\hline 36 & $\begin{array}{l}\text { I think that I made the correct decision to use EB } \\
\text { website and I am satisfied }\end{array}$ & $\begin{array}{l}\text { Casalo et al., } \\
(2008)\end{array}$ \\
\hline 37 & $\begin{array}{l}\text { In general terms, I am satisfied with the way that } \\
\text { the EB website that I use, is carrying out } \\
\text { transactions }\end{array}$ & $\begin{array}{l}\text { Casalo et al., } \\
\quad(2008)\end{array}$ \\
\hline 38 & $\begin{array}{l}\text { In general, I am satisfied with the service I have } \\
\text { received from the EB website }\end{array}$ & $\begin{array}{l}\text { Casalo et al., } \\
\quad(2008)\end{array}$ \\
\hline
\end{tabular}


International Journal of Economics \& Business Administration, I (1), 2013

32 Efstathios Dimitriadis - Athanasios Mandilas - Dimitrios Maditinos

\section{Appendix B}

\begin{tabular}{|c|c|}
\hline Items forming the E- banking dimensions & Loadings \\
\hline \multicolumn{2}{|l|}{ Security } \\
\hline $\begin{array}{l}\text { By using EB I keep my privacy so that other people won't know about my } \\
\text { bank transactions }\end{array}$ & 0,716 \\
\hline I am not afraid that in EB mistakes occur more easily than at bank office & 0,696 \\
\hline When I use EB my money is as safe as when I use other banking services & 0,712 \\
\hline $\begin{array}{l}\text { The EB is a safe place to transmit sensitive information and my bank } \\
\text { information won't fall into the wrong hands }\end{array}$ & 0,685 \\
\hline \multicolumn{2}{|l|}{ Status } \\
\hline By using EB I give a modern impression of myself to other people & 0,762 \\
\hline $\begin{array}{l}\text { By using EB I stand out of ordinary people who use traditional bank } \\
\text { services }\end{array}$ & 0,807 \\
\hline Using EB gives me a more professional status & 0,828 \\
\hline I can have more prestige than other bank customers if I use EB services & 0,851 \\
\hline \multicolumn{2}{|l|}{ Exploration } \\
\hline $\begin{array}{l}\text { It would be useful to exchange opinions with other people in discussion } \\
\text { groups about topics related to banking issues in EB }\end{array}$ & 0,753 \\
\hline $\begin{array}{l}\text { Sometimes it is fun just to browse around and see what can be found on } \\
\text { bank's website }\end{array}$ & 0,814 \\
\hline I would like to read versatile daily news on bank's website & 0,789 \\
\hline \multicolumn{2}{|l|}{ Trust } \\
\hline Even if I am not monitored I trust EB site to do the job correctly & 0,591 \\
\hline $\begin{array}{l}\text { I trust banks reliability in correcting erroneous transactions of EB Services } \\
\text { usage }\end{array}$ & 0,762 \\
\hline $\begin{array}{l}\text { Trust in the bank to compensate for losses due to security using EB } \\
\text { Services }\end{array}$ & 0,767 \\
\hline \multicolumn{2}{|l|}{ Convenience/Usefulness } \\
\hline I believe that EB is trustworthy & 0,604 \\
\hline $\begin{array}{l}\text { Using EB site makes it easier to do my banking activities because the } \\
\text { system provide the precise information I need }\end{array}$ & 0,589 \\
\hline I find the use of the EB to be advantageous & 0,723 \\
\hline Using EB site the productivity of my banking activities is enhancing & 0,676 \\
\hline EB have better prices than office services & 0,530 \\
\hline $\begin{array}{l}\text { EB use helps me to make managing my accounts and doing transactions } \\
\text { easier and quickly }\end{array}$ & 0,723 \\
\hline E use improves my life & 0,634 \\
\hline By using EB I have more time for my family-friends & 0,589 \\
\hline I can perform my banking transactions anywhere in the world & 0,662 \\
\hline I can enjoy 24 hours banking services & 0,679 \\
\hline
\end{tabular}

